\title{
A biosketch of William Richard Gowers with a new review of his inpatient case history notes
}

\author{
Resumo biográfico de William Richard Gowers com uma nova revisão das notas de \\ pacientes hospitalizados
}

Thiago Cardoso Vale', Andrew Lees², Francisco Cardoso ${ }^{3}$

\begin{abstract}
William Richard Gowers (1845-1915) spent his career working at the National Hospital for the Relief and Cure for the Paralyzed and Epileptic at Queen Square, in London, United Kingdom, and at the nearby University College Hospital. His "Manual of the Diseases of the Nervous System" and many published lectures were based almost entirely on his own clinical observations meticulously recorded in shorthand. In this paper, we have focused on an analysis of his inpatient case records from 1878 to 1911 preserved in the archives at the National Hospital for Neurology and Neurosurgery, Queen Square. We reviewed all 42 volumes and analyzed 2,478 patients. Between 1897 and 1909 , a mean of 129.7 cases per year were admitted to the hospital under Gowers' care. We grouped the diagnoses in 12 different categories. Epilepsy (16.5\%), followed by spinal cord diseases (10.3\%), cerebrovascular diseases (9.5\%), and functional disorders (7.9\%) were the most common diagnoses.
\end{abstract}

Key words: history of medicine, epilepsy, cerebrovascular disorders, spinal cord diseases, movement disorders.

\section{RESUMO}

William Richard Gowers (1845-1915) passou sua vida profissional trabalhando no National Hospital for the Relief and Cure for the Paralyzed and Epileptic e no University College Hospital na Queen Square, em Londres, Reino Unido. Seu livro Manual of the Diseases of the Nervous System, assim como suas várias aulas publicadas foram baseadas quase inteiramente em suas próprias observações clínicas, anotadas meticulosamente em estenografia. Neste artigo, o objetivo foi a análise das notas de casos clínicos de pacientes hospitalizados entre 1878 e 1911 armazenadas nos arquivos do National Hospital for Neurology and Neurosurgery, na Queen Square. Foram revisados 42 volumes e analisados 2.478 pacientes. Entre 1897 e 1909, uma média de 129,7 casos foram admitidos ao ano no hospital sob supervisão de Gowers. Os diagnósticos foram agrupados em 12 categorias diferentes. Epilepsia (16,5\%), seguida de doenças da medula espinhal (12,7\%), doenças cerebrovasculares (9,5\%) e transtornos funcionais (7,9\%) foram os diagnósticos mais encontrados nas notas dos casos clínicos.

Palavras-Chave: história da medicina, epilepsia, transtornos cerebrovasculares, doenças da medula espinhal, transtornos motores.

William Richard Gowers was born in 1845 in the London Borough of Hackney, at a time when a number of infectious epidemic diseases were sweeping across Western Europe and causing many fatalities. The fourth child of a Hackney lady shoemaker, by the age of 11 years, Gowers witnessed the death of both his younger siblings and father. His widowed mother then moved out of London to be closer to relatives in Oxford and Gowers "gained an adequate acquaintance of French, German, Latin, a mastery of incisive English of peculiar beauty and clarity, and a most elegant penmanship"1.
Three years later, at the age of 16 , William started to spend his summer holidays working on a farm in Yorkshire and there was a real possibility that he may have ended up as a farmer. He was eventually persuaded by his family that lived in Coggeshall in Essex to accept a two-year medical apprenticeship with one of the village doctors, Thomas Simpson ${ }^{1,2}$. In January 1863, Gowers' family moved to London and he passed the entrance examination for University College London, in which he studied German, Greek, Latin, chemistry, botany, zoology, mathematics, geometry, English, and natural philosophy ${ }^{1,2}$. In 1865, the man embarked on his undergraduate career and had the good fortune

\footnotetext{
${ }^{1} \mathrm{MD}$, Neurology Division, University Hospital, Faculty of Medicine, Federal University of Minas Gerais (UFMG), Belo Horizonte MG, Brazil;

${ }^{2} \mathrm{MD}$, Fellow of the Royal College of Physicians and of the United Kingdom Academy of Medical Sciences, The National Hospital for Neurology and Neurosurgery, Queen Square, London, United Kingdom and the Reta Lila Weston Institute of Neurological Studies, University College London, United Kingdom; ${ }^{3} \mathrm{MD}, \mathrm{PhD}$, Movement Disorders Unit, Neurology Division, Department of Internal Medicine, Faculty of Medicine, Federal University of Minas Gerais (UFMG), Belo Horizonte MG, Brazil.

Correspondence: Francisco Cardoso; Avenida Pasteur 89 / 1107;30150-290 Belo Horizonte MG - Brasil; E-mail: cardosofe@terra.com.br

Support: Francisco Cardoso received research grants from Fundação de Amparo à Pesquisa do Estado de Minas Gerais (FAPEMIG) and honoraria from Roche and Moksha; Professor Andrew Lees has received honoraria from Novartis, Teva, Meda, Boehringer Ingelheim, GSK, Ipsen, Lundbeck, Allergan, and Orion.

Conflict of interest: There is no conflict of interest to declare.
}

Received 20 December 2012; Received in final form 26 December 2012; Accepted 02 January 2013. 
through family connections in the Nonconformist world to be appointed as personal assistant to Sir William Jenner, the senior physician at University College Hospital (UCH) and President of the Royal Society of Physicians. John Russell Reynolds, another Nonconformist member of staff with interest in epilepsy, was also an influential mentor and lifelong friend. MacDonald Critchley (1990-1997) speculates that it would have largely been Reynolds' teaching that directed Gowers' attention towards neurology ${ }^{1-3}$. In 1867, Gowers was admitted as a member of the Royal College of Surgeons and graduated in 1870, after having been awarded an undergraduate gold medal ${ }^{1,2}$.

\section{GOWERS AT THE NATIONAL HOSPITAL IN QUEEN SQUARE}

The historical figure became the first medical registrar to be appointed to the National Hospital for the Relief and Cure for the Paralyzed and Epileptic (nowadays known as the National Hospital, Queen Square) in 1870, ten years after the small hospital had opened its doors for patients. He would spend his entire career there, seeing patients mainly in the outpatient room, teaching students the rudiments of neurology, and carrying out post-mortems ${ }^{1,3}$. Following his appointment, he instigated a diagnostic inventory at the hospital and in his first year, he reported on the treatment outcomes of 500 patients $^{1}$. His master and early inspiration was John Hughlings Jackson, who was considered the founding father of British neurology $y^{1,3}$. Gowers was also nominated to the staff of UCH in 1872, keeping this second appointment for 16 years. In 1875, he married Mary Baines from a well-known Leeds family and Russell Reynolds niece-in-law. They lived at Queen Anne Street in the West End of London, where he had his own private consulting rooms ${ }^{1,3}$.

\section{THE BIBLE}

The period from 1870 to 1890 were his most productive years for research and publications. Critchley described 1879 , in particular, as his annus mirabilis, because he wrote or published four important works as well as shorter papers ${ }^{1}$ : the lectures on epilepsy ${ }^{4}$; a monograph on pseudo-hypertrophic paralysis ${ }^{5}$; his address on the diagnosis of diseases of the spinal cord ${ }^{6}$; and his Manual of Medical Ophthalmoscopy ${ }^{7}$. Towards the end of the 1880s, Gowers' career was approaching its zenith. In 1887, at 42 years-old, he was elected a fellow of the Royal Society and finally consulting physician of the National Hospital in $1888^{1,3,8}$. His achievement as a neurologist was formally recognized by the Queen when he received a knighthood in the Diamond Jubilee honors in $1897^{\circ}$. Sir William Osler would later describe him as "the ornament of British medicine".

Gowers is best remembered for his "Manual of the Disease of the Nervous System". Its first edition appeared in two volumes, published in 1886 and in $1888^{9-11}$. The second one followed in 1892 and 1893. His textbook remains the most outstanding single-author textbooks of clinical neurology that has ever been published. For Gowers, care of patients, research, and teaching were of equal importance. His research was based almost entirely on his own case records, meticulously recorded, filed, and closely analyzed ${ }^{9-12}$.

\section{FINAL YEARS}

Despite increasing ill health, Gowers devoted the rest of his working life to teaching, writing, and practicing neurology. He was forced into retirement at the age of 62, feebled by 'generalized cerebrovascular degeneration'. Therefore, he moved to a more suitable house in Ladbroke Square, where he spent his last years of life. Gowers survived his wife Mary by just two years and died at the age of 68 in 1913, inside his home in the presence of his son, Ernest. His funeral took place at St Peter's Church, Vere Street, in Kensington ${ }^{1-3}$.

The first biography, published in 1949, was written by MacDonald Critchley, who described him as arguably the greatest clinical neurologist that has ever lived ${ }^{1}$. A new biography done by Ann Scott ${ }^{2}$, Gowers' great granddaughter, and two neurologists Andrew Lees and Mervyn Eadie, has recently been published and includes material from the Gowers' family archives, which was unavailable to Critchley. Such book provides numerous illustrations of his medical drawings and etchings as well as previously unpublished family photographs. It also shows new insights into Gowers' personality and his major achievements in neurology based on our current knowledge. Gowers' clinical monographs and published lectures for students in the Lancet and British Medical Journal can still be read profitably today, and many of his clinical descriptions of neurological illness have not been surpassed.

\section{INHOSPITAL DIAGNOSES}

\section{Methods}

During a short fellowship, one of the author of this article reviewed the volumes of Gowers' case notes available at the Queen Square Library, Archive and Museum, National Hospital for Neurology \& Neurosurgery, in London (UK), from 1878 to the time of his retirement (1911). There were 42 volumes and 2,478 patients. Twelve different categories were listed in order to classify the most common diagnoses: epilepsy, cerebrovascular disorders, movement disorders, neoplasm, functional disorders, neurasthenia, disseminated sclerosis, motor neuron disease, neuromuscular disease, peripheral nervous system disease, spinal cord disease, syphilis, among others. The study was conducted according to ethical standards of the Queen Square Library, Archive and Museum, National Hospital for Neurology \& Neurosurgery, London, WC1N 3BG. 


\section{Results}

The most common recorded diagnoses were: epilepsy (16.5\%), spinal cord disease (10.3\%), cerebrovascular disorders (9.5\%), syphilis (8.5\%), functional disorders (7.9\%), neoplasm (7.7\%), and movement disorders (7.7\%). Disseminated sclerosis (sometimes referred to as insular sclerosis, 5.6\%), unspecified lower motor lesions (4.0\%), neurasthenia (3.6\%), peripheral nervous system (3.5\%), and neuromuscular junction disorders $(2.8 \%)$ were also admitted. A total of $12.1 \%$ of cases was classified as miscellaneous for the purpose of this analysis.

The number of case notes per volume ranged from 2 to 175 (mean 79.9 \pm 49.1 ). Gowers reported most of his case notes during the years of 1897 to 1909 , when $68 \%$ of the notes were gathered with a mean of 129.7 cases per year. Figure shows the number of cases hospitalized under the direct or indirect supervision of Gowers from 1878 to 1911.

\section{DISCUSSION}

Gowers laid the foundations for a diagnostic method that remains at the root of clinical training at Queen Square. Gordon Holmes, who arrived at the hospital around the time of Gowers' retirement, then built on Gowers' technique to embellish the detail of the neurological examination. He can also be said to have pioneered the collection of data for clinical research in the hospital through his emphasis on accurate and careful recording of each case that was admitted.

Arguably, his most relevant contribution to neurology was in the field of movement disorders. This was true particularly with his descriptions on Sydenham's chorea after having treated more than 120 children in hospital and many others in an outpatient basis. A recent review in the case notes of Gowers on chorea showed that his description of the phenomenology and natural history of chorea is in keeping with our current notions about the illness. His observations on this hyperkinetic disorder show that, unlike many of his contemporaries, he had a clear understanding of chorea as a syndrome distinct from other phenomena. Moreover, he was

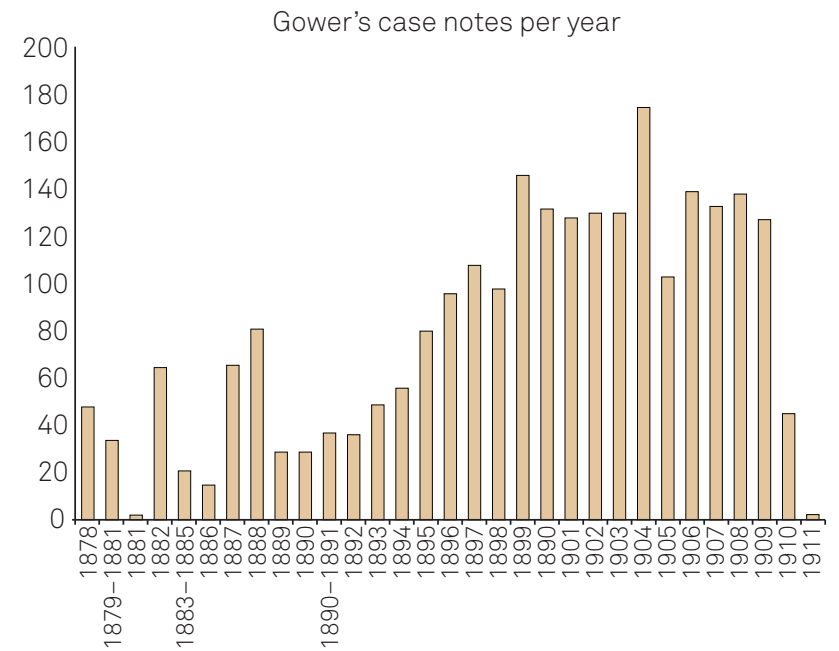

Figure. Distribution of Gower's case notes per year (from 1878 to 1911).

able to define that it could result from a myriad of conditions, such as rheumatic fever, stroke, Huntington's and Wilson's disease, among others ${ }^{13}$.

Gowers also defined the clinical features of nearly 1,500 personally observed epilepsy cases, material which he later used in his monograph entitled "Epilepsy and other chronic convulsive disorders", in $1881^{4}$. In 1901, a second edition was published with 3,000 cases of epilepsy covering mainly its clinical symptomatology.

The contribution of such character to other branches of neurology including neuromuscular diseases, neuro-ophthalmology, and spinal cord diseases is evidenced by his historical monographs on Pseudo-hypertrophic muscular paralysis ${ }^{5}$, Manual and atlas of medical ophthalmology? and Diagnosis of the Diseases of the Brain and the Spinal Cord ${ }^{6}$.

This brief view of Gowers' case notes of the National Hospital, Queen Square, shows that by 1880 he had developed a scheme of history taking and examination that approximates closely to the current one. These notes and those of other physicians formed the basis of Queen Square contribution to clinical neurology, in which Gowers' Manual is still referred to by trainees and members of the staff as 'the Bible'.

\section{References}

1. Critchley M. Sir William Gowers 1845-1915: a biographical appreciation. London: William Heinemann Medical Books; 1949

2. Scott A, Eadie M, Lees A. William Richard Gowers 1845-1915: exploring the Victorian Brain. Oxford: Oxford University Press; 2012.

3. Holmes SG. Sir William Gowers at the National Hospital. BMJ 1951;2:1397-1398

4. Gowers WR. Epilepsy and other Chronic Convulsive Diseases. London: J \& A Churchill; 1901.

5. Gowers WR. Pseudo-hypertrophic muscular paralysis. London: J \& A Churchill; 1879.

6. Gowers WR. Diagnosis of the Diseases of the Brain and of the Spinal Cord. New York: William Wood \& Co; 1885.
7. Gowers WR. A Manual and Atlas of Medical Ophthalmoscopy. London: $J \&$ A Churchill; 1879.

8. Holmes G. The National Hospital Queen Square. Edinburgh:E\&SLivingstone;1954.

9. Gowers WR. A Manual of Diseases of the Nervous System. London:J \& A Churchill; 1886 .

10. Gowers WR. Lectures on the Diagnosis of Diseases of the Brain London:J \& A Churchill; 1887.

11. Gowers WR. A Manual of Diseases of the Nervous System. London: J \& A Churchill; 1888.

12. Tyler KL. William Richard Gowers (1845-1915).J Neurol 2003;250:1012-1013.

13. Vale TC, Glass PG, Lees A, Cardoso F. Gowers' Queen Square case notes on chorea: a 21st century appraisal. Eur Neurol 2013;69:48-52. 